\title{
On the periphery of the parts of speech system
}

\author{
Rakhim Z. Muryasov
}

DOI: 10.18355/XL.2019.12.04.05

\begin{abstract}
The article is devoted to the consideration of the periphery of the parts of speech system. The theory of parts of speech, constituting the core of the theory of grammatical structure and serving as the basis for describing the linguistic system as a whole, is an area of controversial debates in the context of various linguistic paradigms. The internal contradictions inherent in the language system do not allow developing integrated, logically consistent criteria for the classification of lexis, covering all categories of words. The functional-semantic and formal heterogeneity of lexical categories does not make it possible to include them into "the Procrustean bed," a scheme recommended by various linguistic schools. The most contradictory classifications are the ones of the so-called synsemantic, functional words which are characterized by a high degree of categorical interpenetration. The determination of the categorical status of this kind of words is possible only on the basis of semantic and pragmatic features of discourse, as well as when taking into account presupposition factors.
\end{abstract}

Key words: auto-and synsemantic parts of speech, prepositions, conjunctions, particles, interjections, onomatopoeic words

\section{Introduction}

\subsection{The Problem Statement}

Parts of speech, making the fundamental category of the language system, have been the object of contradictory discussions for centuries and remain one of the controversial issues at present (Simsek, Elciyar, Kizilhan, 2019). The classification of parts of speech is based on a number of criteria: semantic (the generalized lexical meaning), morphological (the combination of grammatical categories with the corresponding paradigms), and syntactic (functions of words in a sentence) (Valeeva, Aitov, Bulatbayeva, 2016; Sum, Kwon, 2018). The difference between autosemantic and synsemantic words and synsemantic groups of words also lies in the fact that the former form open classes of words and it is almost impossible to determine their quantitative composition (the exceptions are pronouns and numerals), whereas the latter can be regarded as closed or relatively closed classes (Geng, 2017; Uzun, 2018). The aim of the article is to consider the periphery of the parts of the speech system.

\subsection{Literature Review}

The complexity of the problem, even within one language, is primarily due to two reasons. Firstly, not all parts of speech are equally characterized by all the features listed above, secondly, due to the interpenetration parts of speech (Paul, 1960; Wierzbicka, 1976; Weydt, 1977; Krivonosov, 1977; Eisenberg, 1994; Hellbig, Buscha, 1996; Gak, 2000; Nikolayeva, 2005; Muryasov, Samigullina, 2013; Riegel, Pellat, Rioul, 2014; Di Paola, 2016; Zheltukhina et al., 2016; Gyamfi, Sukseemuang, 2017; Alipichev et al., 2017; Köprülü, Öznacar, 2017; Korkmaz, Güneyli, 2017; Boeva-Omelechko et al., 2018).

While studying the issue of parts of speech in different linguistic systems simultaneously, the different status of each of the above features is revealed. The most vulnerable criterion is the so-called generalized semantic feature, which was pointed out frequently by home and foreign linguists, as words of different parts of speech in

XLinguae, Volume 12, Issue 4, October 2019, ISSN 1337-8384, eISSN 2453-711X 
the "deep structure," i.e. at the conceptual level are not included in the opposing relationship, cf. Russian: бег - бегать - беготня; German: laufen - der Lauf - das Laufen - die Lauferei. These lexical units are associated with the general concept of "movement" or even at a higher level of abstraction "action."

If for Russian, German and Turkic the morphological feature is sufficiently consistent - a widespread inflectional paradigmatics, then in English and French the morphological feature of opposing parts of speech is asymmetric in the sense that the verb is rich in morphological paradigmatics, while the morphology of nouns is reduced to the oppositions of the category of "singularity: plurality".

Adjectives in the Russian and German languages are characterized by a rich inflexible paradigm, and in the English and Turkic languages (for example, in Bashkir and Tatar), they are amorphous, apart from the category of degrees of comparison, $\mathrm{cf}$. English clever boy - of a clever boy - with a clever boy - clever boy's successes and Bashkir akylly malai - akylly malaithyng (gen. case) - akylly malaiga (dat. case) akylly malaithar (pl. number), etc. As for the French language, the adjective agrees with the definable noun in gender and number.

At the same time, the grammatical category of comparison of adjectives is common for all the above-mentioned languages: in Russian and German with dominance of synthetic characteristics, in English and Turkic a certain balance is observed between synthetic and analytical means, and in French this category is expressed analytically (large-plus large - le plus large).

\section{Methodology}

The research method can be described as a complex one since it has included different types of analysis: semantic, morphological, syntactic and comparative analyses.

Along with the indisputable canonical parts of speech, which, for example, are nouns and verbs, clearly contrasted primarily in terms of morphological paradigm and their grammatical categories, there have always been distinguished classes of words, the parts of speech status of which caused certain reservations, such as pronouns and numerals. Besides, the status of some classes could not be justified by the criteria on which such indisputable parts of speech as nouns and verbs were based, which resulted in the identification of a special group of words, called particles of speech in home linguistics or synsemantic words in the works of foreign scholars.

Synsemantic parts of speech perform heterogeneous functions in language and discourse.

1. Prepositions and conjunctions are characterized by structural content; namely, they perform the functions of linking between members of a sentence and clauses - the components of complex sentences.

2. Categories of words, the categorical status of which causes controversial debates. Thus, particles reveal connections; on the one hand, with the structure of a sentence or even its parts, on the other hand, they are characterized by discourse-oriented features that go beyond the framework of the sentence.

3. Interjections take a specific place not only in the language system but also in the periphery of the system of parts of speech. The most controversial is the status of onomatopoetic words (onomatopoea), which are included, as a rule, without any scientific arguments, in the class of interjections.

Classes of words that form the periphery of the system of parts of speech are called "particles of speech."

The term "particles of speech" is used in linguistic literature in two meanings:

1) denoting synsemantic parts of speech in general (prepositions, conjunctions, particles in the narrow sense of the term, and sometimes also interjections); 
2) denoting a class of words performing communicative and pragmatic, discourseoriented functions in the text, i.e., particles in the narrow sense.

\section{Results and Discussion}

\subsection{Morphological Structure and Status of Prepositions and Conjunctions}

Synsemantic words are grammatically amorphous. This feature results in diffusion of the boundaries among separate parts of speech, especially among prepositions, conjunctions, particles, and adverbs: cf. 1. preposition + adverb: Russian; вдоль, вдогонку, возле, вокруг, за...; 2. preposition + conjunction: English: until; German: seit; 3. preposition + conjunction + conjunction adverb: German: waehrend; 4. conjunction + preposition + pronoun: English: as; 5 . conjunction + preposition + adverb: English: since, before; 6. preposition + conjunction + adverb + adjective: English: after; 7. conjunction + adverb: German: solange; French: comme; 8. adverb + particle: Russian: очень, вовсе, уже, почти; English: very, simply, exactly, mainly; German: sehr, beileibe, schon, also, mal, erst; French: déjà, plus, moins, aussi, un peu, là, même, tellement, etc.; 9. particle + conjunction: Russian: ведь, ли, да, же, именно, etc.; 10. particle + interjection: Russian: ну; French: quоi moi; 11. adverb + particle + conjunction: Russian: разве; German: also, so; French: si; 12 . particle + conjunction + adverb + interjection: Russian: точно, только, едва ли не; 13. adverb + interjection + particle: Russian: очень; English: indeed; 14. particle + sentence equivalent: Russian: да, нет, спасибо, пожалуйста; English: yеs, по, please, thanks; German: bitte, ja, nein; French: oui, non, etc.

Thus, from the point of view of categorical characteristics, at the level of parts of speech, monocategorial (monofunctional) and polycategorial (polyfunctional) synsemantic units are distinguished. Mono-categorical ones include such units which function only as one part of speech. Let us demonstrate this by the example of

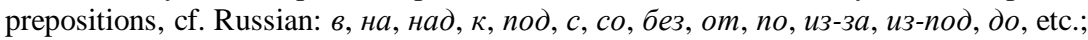
English: at, against, among (amongst), for, from, of, etc .; German: bei, dank, gemä $\beta$, gegenüber, mitsamt, nebst, samt, etc.; French: à, chez, de, en, entre, par, parmi, pour, sans, vers, etc. Polyfunctional prepositions and other synsemantic units are mentioned above.

In the typological aspect, the questions of the structure of synsemantic words are of interest. In all analyzed in this article Indo-European languages, there are simple derivatives, complex and compound (poly component) units, between which, depending on the language, there may exist relations of equivalent symmetry and asymmetry. Simple prepositions that have equivalents in different languages: Russian: в, для, за, из, $к$, etc; English: in, for, from, to, besides, etc; German: in, für, von, zu, außer, etc.; French: en; pour, de, chez, vers etc. Equivalent polycomponent (composite) prepositions: Russian: в течение, в случае, с иелью, по сравнению, со стороны кого-л.; English: in the course of, in the case of, with the view of, for the purpose of, with the purpose of; German: im Verlauf von, im Falle, zum Zweck, im Vergleich zu, von Seiten, vonseiten, seitens; French: au cours de, au cas où (union), en vue de, en comparaison de, du côté de, etc.

Between simple and compound prepositions, structural asymmetry is often observed, namely, the univerbal preposition (simple, derivative or complex) in one language can have a correspondence in another language in the form of a composite preposition, cf.: Russian: ввидy, English: in view of, German: angesichts, French: face à; Russian: впереди, перед; English: in front of; German: vor; French: devant; Russian: в пользу; English: in favor of; German: zugunsten, zuliebe; French: en faveur de; Russian: взамен; English: in return for; German: an Stelle, anstelle; French: à la place de, etc. In different languages, on the one hand, and in works of different authors, in the framework of one language, on the other hand, there is a mixed picture, which is 
manifested in the incongruity of the variety of prepositions and in their different numbers. Simple prepositions, by which we mean single-morpheme units, have more or less stable amounts, cf. Russian: перед, за, до, без, $c$; English: at, above, to, with; German: auf, an, aus, mit, ohne; French: chez, par, sans, avec. In the Latin language, almost all prepositions are simple. The exception is 2 prepositions - adversus "against, on the contrary," and absque "without smth., far from." If simple prepositions form a relatively closed class, this characteristic cannot be given to composite prepositions, i.e. multicomponent prepositions, which in their structure are similar to free word combinations. This particular class of prepositions is constantly enriched by word combinations. Some composite prepositions become complex ones, which is especially characteristic of the Russian and German languages, cf. $в+$ neped $\rightarrow$ впереди, на + против $\rightarrow$ напротив; German: an Stelle $\rightarrow$ anstelle, von Seiten $\rightarrow$ vonseiten, mit Hilfe $\rightarrow$ mithilfe, auf Grund $\rightarrow$ aufgrund.

Thus, by their structure, prepositions are divided into 4 groups: simple, i.e. single morphemes, derivatives, i.e. having affixes or going back to the grammatical forms of one or another part of speech (Russian: в, позади, среди, благодаря, исключая; German: anfangs, angesichts, betreffs, mangels, mittels, anlässlich, hinsichtlich, dank, kraft, trotz, entsprechend, ausgenommen; French: attend, vu, passé, excepté, durant, touchant, concernant, etc.); complex, representing the combination of two prepositions or a simple preposition with an autosemantic word into one univerbal unit (English: into, onto, throughout, without; German: inmitten, aufgrund, mithilfe; French: jusque, par-dela, etc.); 4. composite (two-membered, three-membered, fourmembered) prepositions by the number of their components form three subgroups.

When describing composite prepositions some lexicographical sources contain such formulations, which indicate the intermediate nature of some structures. Thus, in (Shvedova, 1980), in the description of the semantic structure of lexical units, in addition to different sememes, there appears the wording "in the meaning of a preposition," for example, direction: in the direction to someone, in the direction from something. ; relation: in relation to someone smb., in relation to; force: by force; view: in view of; side: towards smth., away from smth.; reason: because of smth. etc. There are also certain inconsistencies. For example, the structure from the side (from the side of a forest, river, etc.) is not considered as a word combination "in the meaning of a preposition."

The same complicated picture is revealed when analyzing the structure of conjunctions, within which one can also single out mono- and multicomponent units. Conjunctions form heterogeneous classes of words in their structure. In all languages, monocomponent and multicomponent structures are distinguished. However, the proportion of multicomponent structures is not the same for different languages. If there are two-, three-, and four-component conjunctions in the Indo-European languages, in Turkic languages, two-component conjunctions are few, and threecomponent conjunctions are isolated cases. According to the structure, conjunctions are divided into the following groups:

1. Simple, i.e. root conjunctions: Russian: если, как, что, ибо, благо, хотя, хоть, nусть, пускай, etc.; English: and, but, or, after, as, before, since, till, when, while, if, etc .; German: aber, oder, und, denn, doch, wie, dass, weil, ehe, als, wenn, etc.; French: et, ou, mais, car, donc, que, si, quand, comme, etc.; Latin: autem, at, et, que, ac, etiam, tamen, nam, enim, etc.

2. Derivative and complex conjunctions: Russian: чтобы, поскольку; English: whereas, unless; German: jedoch, sowie, beziehungsweise, indem, indessen, sobald, solange, sooft, nachdem, sodass, damit, obwohl, obshon, obgleich, obzwar, wenngleich, etc.; French: néanmoins, toutefois, enfin, lorsque, puisque; Latin: atque, neque, quoque, atqui, quandoque, quando-quidem, quantum vis, quamquam, etc.

3. Two-component conjunctions, i.e. consisting of two formally independent words: Russian: потому что, так как, лишь бы, только бы, так что, словно как, вроде 
как, как и, подобно тому, etc.; English: in case, provided (that), supposing that, so that, as if, notwithstanding that, etc.; German: das heisst, als dass, sodass, (an) statt dass, ohne dass, als ob, als wenn, ausser dass, kaum dass, im Falle, wenn auch, je nachdem, ausser wenn, etc.; French: ou bien, au contraire, par contre, en revanche, par subsequent, par suite, consequently, a savoir, alors que, avant que, après que, dès que, etc.;

4. Three-component conjunctions: Russian: до того как, при условии что, из-за того что, при том что, вопреки тому что, так же как, подобно тому как, вроде того как, все равно что, между тем как, etc.; English: as well as, as long as, as soon as, so long as, for fear that, in order that, etc; German: es sei denn, umso mehr als, umso weniger als; French: en attendant que, aussi longtemps que, à mesure que, une fois que, du moment que, de façon que, à condition que, etc.;

5. Four-component conjunctions: Russian: c mех пор как, точно так жекак, в результате того что, в силу того, что, независимо от того, что, при всем том, что, в то время как, по мере того как; English: on the ground that; French: en même temps que, à ce point que, c'est-à-dire.

Five-component and six-component conjunctions are extremely rare: (English: in spite of the fact that; French: au fur et à mesure que.

In some cases, structural asymmetry between conjunctions takes place in different languages, in the sense that a poly component conjunction in one language can correspond to a simple conjunction in another language, cf. the English conjunction as in the temporal meaning corresponds to a two-component compound conjunction alors que "whereas; while" in French, and in comparative terms in French it corresponds to a six-component compound conjunction, cf. English things get more difficult as the year goes on - French ça va devenir de plus en plus difficile au fur et $\grave{a}$ meres que la fin de l'année aproche.

Many compound conjunctions are formed from prepositions and other parts of speech by adding simple conjunctions, the most frequent of which are чmo and как in Russian, that in English, dass in German and que in French, cf. Russian: несмотря на то что, невзирая на то что, вопреки тому что, так же как, вроде того как, тогда как, etc.; English: seeing that for, for fear that, so that; German: als dass, so dass, (an) statt dass, ohne dass, ausser dass. Special productivity in the formation of compound conjunctions in French is shown by a simple conjunction que: allors que, avant que, après que, dès que, aussitôt que, en attendant que, aussi longtemps que, en même temps que, à mesure que, à condition que and many others.

\subsection{On the Term "Particles", Their Types and Status}

If prepositions and conjunctions are practically recognized in almost all grammars of different languages, then the range of opinions on the status of particles, interjections, and onomatopoeic words is quite varying. Thus, in the opinion of many linguists, particles do not form a separate part of speech but are considered as subclasses of adverbs. For example, in German-language linguistic literature there are two diametrically opposed approaches to determining the status of particles in the narrow sense of the term. In some grammars of the German language particles form an independent part of speech. In other grammars particles are classified as adverbs. $\mathrm{H}$. Paul (1960), in his classic work - the catechesis of the Neogrammarian school of linguistics "Principles of the History of Language" does not mention such a part of speech as particles.

Some German linguists point to different ways of solving the question of the status of particles. On the one hand, particles cannot be recognized as parts of speech and, therefore, should be included in adverbs. On the other hand, a special group of classes of words called "unchangeable words" (Nichtflektierte) should be distinguished,

XLinguae, Volume 12, Issue 4, October 2019, ISSN 1337-8384, eISSN 2453-711X 
within which adverbs, conjunctions, prepositions, particles are represented (Duden, 2005; Eisenberg, 1994; Gak, 2000; Grammatik der deutschen gegenwartssprache, 1997; Hellbig, Buscha, 1996); H. Weydt (1997), A.T. Krivonosov (1977) consider that all unchangeable classes of words should be united under the common name speech particles, including adverbs (Adverbialpartikeln), conjunctions (Konjunktionspartikeln), prepositions (Präpositionspartikeln), modal particles (Abtönungspartikeln), degree particles (Gradpartikeln), etc. (Krivonosov, 1977; Weydt, 1977). With such an approach to the unchangeable parts of speech, the particles are divided into several classes, which occupy an equal position in the hierarchy of the parts of speech with prepositions and conjunctions. No less controversial in the German grammatical tradition is also the categorical status of modal words related to adverbs (Duden, 2005), recognized as an independent part of speech (Eisenberg, 1994), or called sentence equivalents (Satzäquivalente).

The absolute denial of the parts of speech status of particles is represented in the works of a number of German scholars. Thus, P. Eisenberg (1994) writes: "Es gibt keine Ausdrücke, die nur Abtönungspartikeln sind ... Etwas Ähnliches gilt für die Gradpartikeln”. P. Eisenberg (1994) believes that the role of particles in forming a sentence is negligible. He compares particles with insects on fur ("die Partikeln, diese Zaunkönige und Läuse im Pelz der Sprache" - literally particles are wrens and parasites in the body of the tongue) (Eisenberg, 1994). This opinion of P. Eisenberg (1994) is not shared unconditionally by other Germanists. The role of particles in the discourse, especially in colloquial speech, is considered by many linguists as an indisputable fact. T.M. Nikolayeva (2005) indicates their "communicative freedom" (Nikolayeva, 2005). The author writes, "The theory of presupposition was a new and powerful device for describing particles, which made it possible to turn the semantics of the "additional line" that does not directly come from the literal composition of the sentence" into the linguistic fact" (Krivonosov, 1977; Hellbig, Buscha, 1996). And then, "particles are carriers of additional hidden semantics" (Nikolayeva, 2005).

A. Wierzbicka (1976) gives a very accurate characterization of particles "... particles have the ability to express the full range of pragmatic meanings at the lowest price" (Wierzbicka, 1976).

A particle in order to realize its hidden potential needs discourse. It is in the discourse where the factors of presupposition and the complex of pragmatic connotations are revealed. The authors of the German-language grammar of the Duden series point out, "Fast alle (sic! - R.M.) Abtönungspartikeln haben Homonyme in anderen Wortklassen (Adverbien, Adjektiven, Kommen-taradverbien, Fokuspartikeln, Konjunktionen, Subjectiones), aus denen Sie sich oft sprachgeschichtlich entwickelt haben" (Duden, 2005). Thus, not all particles have homonymous parallels in the form of other parts of speech. Obviously, most particles have this kind of homonyms. Even within one utterance, the same formally identical unit is a representative of different parts of speech, cf. German Das Leben ist eben (particle) nicht eben (adverb) (Life is just not that simple). P. Eisenberg's (1994) idea that there are no such words that would only be particles is controversial with respect to the given class of words in German and other languages, cf. German: na, übrigens, halt; grammatical particles in English and German to and $z u$ before the infinitive form of the verb; French $-d a$. V.G. Gak (2000) refers - $\dot{c} i$, -la, ne, quant, voire to the actual particles.

As for the Russian language, linguists distinguish in it a whole class of form-

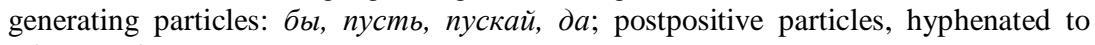

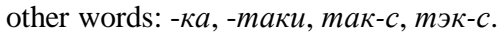

Different categories of particles are sometimes included in the class of different parts of speech or other groups of words.

In the English language linguistic tradition there is also no unanimity in the understanding of the term "particle." In Webster's dictionary, particles include 
articles, prepositions, conjunctions ("a small word of functional or relational use, as an article, preposition, or conjunction ..." (Webster's encyclopedic, 1996).

The authors of the Macmillan (2007) dictionary also include adverbs into the class of particles (an adverb or preposition used to write a phrasal verb" (Macmillan, 2007).

In the Longman dictionary, one finds the following definition of particles: "Any of a number of usu. "For the words of the subject, verb, etc.: prepositions and conjunctions are particles" (Longman, 1998).

In the English grammar of the Longman (1999) series, the term "particles" is referred to prepositions, conjunctions, but particles in the narrow sense of the word are not presented as part of speech. Some units which are traditionally referred to particles are defined as unique words, for example, the negative particle not is characterized as follows, "Not is in many ways like an adverb, but it has special characteristics which make it natural to single it out as a unique member of a class by itself" (Longman, 1999). The grammatical particle to is characterized in the same way, "The infinitive marker to is another unique word which does not easily fit into any of the other classes" (Longman, 1999).

The categorical polyfunctioning of particles is eliminated as a part of concrete sentences or even wider in discourse.

In terms of the particle structure, the following types can be distinguished in the compared languages:

1. Simple (root). As a rule, they are monosyllabic, cf. Russian: де, ишь, ведь, же, еще, уж, чай, не, ни, etc.; English: even, the, just, too, no, not, well, still, right, yet, etc.; German: ja, auch, wohl, doch, nur, halt, sehr, fast, so, recht, man, mal, bloß, shon, nicht, etc.; French: -ci, -la, ne, si, quant, voire, -da, oui, bien, plus, comme, mais, sur, bref, done, etc. Only some root particles are disyllabic, cf.: Russian: ладно, таки, небось, дескать, поди, ровно, словно, право, etc.; English: very, never, either, neither, etc.; German: wenig, etwas. Extremely rare are three- and four-syllable particles: Russian: спасибо.

2. Derivatives and complex particles which are characterized by unclear wordformation motivation: Russian: все-таки, только-лишь, действительно, вовсе, решительно, совершенно; English: simply, precisely, precisely, merely, nearly, scarcely, hardly, etc.; German: äußerst, besonders, einfach, eigentlich, ruhig, überaus, zutiefst, etc.; French: autant, plutôt, puisque, seulement, tellement, etc.

\subsection{Morphological Structure and Status of Interjections}

As for interjections, H. Paul (1960) defined them "as sounds involuntarily escaping from a person, caused by a state of effect, including even those that are not at all connected with the intention to make a message." The author of the catechesis of the Neogrammarians divided parts of speech into three groups: first, such words "which are sentences themselves", H. Paul (1960) includes interjections to this group, which, in his opinion, should be considered as "defective sentences" (Paul, 1960); secondly, such words, "which are able to act as members of a sentence," and, thirdly, words, "which serve only as links between members of a sentence, i.e. functional words". Thus, in H. Paul's grammatical concept interjections are a part of speech.

In the Russian linguistic tradition, the most common is the point of view, according to which interjections are neither a significant nor official part of speech. In other words, interjections form a special category of vocabulary that cannot be qualified as a part of speech. Apparently, this circumstance predetermines the unstable status of this class of words in grammatical research based on different languages.

The authors of Longman Grammar of Spoken and Written English include interjections, along with some adverbs and introductory words, in the class of the socalled discourse markers, "Other interactive conversational inserts are interjections

XLinguae, Volume 12, Issue 4, October 2019, ISSN 1337-8384, eISSN 2453-711X 
and response forms such as oh, ah, right, yeah and okay, which, like discourse markers, can either stay alone, (clearance is mine - R.M.) or attach themselves to larger discoursal units" (Longman, 1999).

From the point of view of the morphological and syntactic structure, interjections, as well as functional parts of speech, are divided into simple, complex, and composite. Simple ones, in the terminology of Russian Grammar, are prototypic (simple) and non-prototypic (derivative) (Shvedova, 1980). Prototypic (simple) interjections include those ones which do not reveal any link with the words of other parts of speech (see the table of phonetic models). Non-prototypic (derivative) interjections single out one-component (root) interjections that go back to different parts of speech, derivative and complex ones, composite interjections, formally corresponding to word combinations, and composite ones, often characterized by the structure of an imperative sentence.

One-component interjections, going back to nouns: Russian: Боже! Горе! Беда! Ужас! Табак! etc., English: Jesus! (God!), Heaven! (God!), etc., German: Jesus Mensch! (Hey, you! Listen! (expresses bewilderment, surprise)), Mann! (Listen to this!), etc.; French: Dieu! (God!) Jesus! (Good God!), Ciel! (Oh, god!), Courage! (Bolder!), Silence (Hush!), etc.

One-component interjections going back to verb forms: Russian: nростите, прости (in the meaning of "not very much"), подумаешь, брось, будет, скажите, хватит, глядь, погоди, постой, давай, вали, etc.; English: come; German: verdammt, verflucht; French: tenez! (hey! how! well! this way!), dis!, dites! donc!, écoute!, écoutez!, va!, allez!, allons! etc.

Derivatives and complex interjections, cf. English: uh-huh. ooh-la-la. yo-ho-ho. booya hy-yi; German: Menschenskind! (unceremonious exclamation expressing surprise), Donnerwetter! (unceremonious ugh, yuck1 disgucting!); Mahlzeit! (Enjoy your meal!, To your health! Hello!), etc.; French: Attention! (Caution!) Formidable! Admirable! (Remarkable!); Russian: Батюшки!, Матушки!, Ей богу!, Ей-же-ей!

Phraseological interjections and interjections-phrases: Russian: боже правый, черта с два, чтоб тебя, ну уж, черт-те что, мать честная, господи Иисусе, вот так номер, вот так клюква, вот тебе раз, подумать только, etc.; English: Jesus wept! (damn it!), bloody hell! (damn it! damn it!), why the devil? (what the hell?) Jesus Christ! (God! Damn it!), good / gracious Heavens! (O God! My God!); German: gerechter Himmel! (My goodness!), Gütiger Himmel!. ach du lieber Himmel! Himmel noch (ein) mal! (Lord! My God!) Pfui Teufel! (oh shit!), oh Gott! (Oh my God! My God!), French: Jésus Marie Joseph !. Jésus Dieul (My God! Good God!), Au diable! (damn it!), ma parole!, ma foi! (I swear by honor!), etc.

Sometimes phonetically identical in different languages interjections can have different meanings French ä̈e! (aj) expresses pain, grief, unpleasant surprise, disappointment, while in English aye (ai) in the sailors' language expresses 1) yes, sir! 2) me! (by roll call) (Apresyan, 2000); cf. next: German oh, la, la! "wow! well, well, well!" English aoh-la-1a! (reaction to boasting, desire to make an impression); French oh la la! (a means of enhancing any emotion): Oh! Quelle chances! Oh la la! "What luck!". Frequently, interjections take part in creating phraseological units, idioms, untranslatable or difficult to translate into another language, the specificity of which, like other phraseological units with emotional meaning, is "associated with the reflection of certain cultural codes" (Shvedova, 1980).

Some interjections are often found in combination with other interjections or in other words, "Oh also frequently combines with other inserts: Oh well, Oh God! Oh, I see it, Oh yeah, Oh yes, Oh no, Oh aye” (Longman, 1999).

The functions of one interjection can be determined on the basis of several contextual indicators: French Ah bah! ( expresses carelessness), ah bien! (protest, expression of surprise), ah là là! (annoyance), ah mais! (rejection, contradiction), ah misère! (annoyance), ih mon Dieu! or eh Dieu! (anger, indignation), ah voila! (expresses 
understanding of something, resentment). There are plenty of such examples from different languages. On the basis of the above-mentioned examples, we consider it rational to speak not about homonymy, but about contextual (discourse) polysemy.

Thus, interjections form periphery in the lexico-grammatical classification of the vocabulary of the language.

Therefore, it can be claimed that interjections are discursively- and situationallyoriented pragmatic units of communication. Interjections are the simplest and most economical means of expressing an emotional assessment of something from the point of view of a communication participant using a certain intonation model, which can be sad, inspired, etc.

In the modern English grammar of foreign authors, there is a tendency to revise the traditional classification of parts of speech. Thus, the authors of the fundamental research "Longman Grammar of Spoken and Written English" divide the vocabulary of the language into three major classes of words: 1) lexical units (lexical words these include nouns, verbs, adjectives, and adverbs); 2) functional units that form closed classes; 3 ) the third group of words called inserts, forming the periphery of the vocabulary, but easily inserted into the discourse, especially in colloquial speech (Longman, 1999).

In this grammar, the following groups of insertion units are distinguished: 1 . interjections, 2. forms of greeting and farewell, 3. discourse markers, 4. words of attention (attention signals), 5. units encouraging a certain reaction (response), 6. positive or negative responses (responses), 7. hesitations, doubts, 8. forms of gratitude, 9. expressions of politeness (please), 10. apologies, 11. units constantly inserted into speech (expletives).

Thus, in this classification, interjections are lowered in their linguistic rank and are considered as one of the groups of inserts. It should also be noted that in this grammar, the units considered in traditional grammar as interjections are divided into 11 groups of units under the common name inserts, and interjections are only one of these classes, for example: Tt oh! Ouch my neck hurts. Oh dear! What's that? And such units as hey, hey hey hey hey, yeah, alright, erm, er, oh Jesus, etc. are not referred to interjections, but to other groups of inserts.

As far as the French language is concerned, in modern foreign linguistic literature an extensive class of units is included in the class of interjections, namely, the so-called "pure" interjections (ah!, bah!, bof!, ha!, hé!, ho!, oh!, hein!, heu!, aïe, etc.) and words of other parts of speech (nouns, adjectives, verbs, adverbs). Sometimes a different categorical status can be assigned to some of the units. In this regard, the authors of the grammar of modern French write: "Des occurences comme Miserable! ou Pitié!, peuvent être interprétées comme des interjections nominales ou comme des phrases nominales à un élément (Riegel, Pellat, Rioul, 2014).

A comparative analysis of interjections on the material of the English, German, and French languages shows that practically it is impossible to determine the number and variety of interjections in a language. Often, one and the same unit is characterized by different categorical parts of speech status in different linguistic sources.

It is impossible to ascribe to most interjections, isolated from the discourse in which they are used, any semantic features. Here is a list of the so-called meanings compiled on the basis of dictionaries of various languages: surprise, fright, emotional excitement, admiration, delight, surprise, fear, awkwardness, anxiety, pain, anger, annoyance, doubt, joy, indignation, suspicion, disgust, contempt, regret, relief, order, request, warning, approval, appeal, satisfaction, dissatisfaction, indifference, ridicule, gloating, threat, horror, etc. (Webster's Encyclopedic, 1996; Longman, 1998; 1999; Kuznetsov, 2000; Yartseva, 2002; Duden, 2005; MacMillan, 2007, etc.)

XLinguae, Volume 12, Issue 4, October 2019, ISSN 1337-8384, eISSN 2453-711X 
Although such a wide range of meanings, home, and foreign linguists attempt to determine the invariant meaning of interjections. Thus, for example, in interjections are defined as "a class of unchangeable words that serve to express indivisible emotional and emotionally volitional reactions to the surrounding reality." A somewhat different approach to determining the meaning of interjections is found in Longman Grammar, the authors of which consider that the meaning of interjections lies in their pragmatic function ("We also comment briefly on their meaning - this is their pragmatic function" (Longman, 1999).

In modern research on the grammatical structure of languages and lexicographical sources the class of interjections is interpreted in a wide sense. We believe that the words included in the class of interjections should be of the anthropomorphic (anthropogenic) character, which is due to the definitions given above. For this reason, we consider it incorrect to include in the class of interjection words expressing sounds produced by animals or emerging from the contact of inanimate objects with different physical properties.

Thus, in the strict sense of the term, words and phrases expressing the emotional state of a person can be attributed to the core of interjections, while words and phrases expressing appeals, i.e., the will of the speaker refer to the periphery. Consequently, onomatopoetic words (onomatopoetica) do not refer to interjections but form an independent class of words, consisting of many groups depending on the physical nature of the objects associated with various sounds, as well as with their source.

\subsection{Functional Potential of Interjections}

When describing the functional potential of interjections, it seems appropriate to introduce the concept of "discourse-oriented value." Let us demonstrate the discursive dependence of the functions of interjection $a x$ by the example from "Master and Margarita" by M.A. Bulgakov (Bulgakow, 1983; Bulgakov, 1996, 2005, 2006) (in 4 languages: Russian, English, German and French) and "Virgin soil upturned" by M.A. Sholokhov (Cholokhov, 1937; Sholokhov, 1976; 1979; Scholochow, 1968) / (in 5 languages: English, Russian, German, French and Tatar).

\section{Bulgakov's texts:}

\section{Expressing satisfaction with something:}

Russian. - Ax, как приятно ужинать вот этак, при камельке, запросто, дребезжал Коровьев - в тесном кругу...;

English "Oh, how nice it is to dine like this, at home," tinkled Koroviev's voice, just among friends...";

German "Ach, wie angenehm ist es doch, so vor einem Kaminfeuer zu Abend zu speisen," schwatzte Korowjew, "im engsten Freundeskreis...";

French - Ah! comme c'est agréable, chevrota Koroviev, de dîner comme ça, auprès d'un bon feu, et à la bonne franquette, en petit comité.

\section{Expressing annoyance, regret:}

Russian - Ax, не напоминайте мне, Азазелло! Я была глупа тогда;

English "Oh, don't remind me of that, Azazello, I was so stupid then";

German "Ach, erinnern Sie mich nicht daran, Asasello, damals war ich dumm;

French Ah! ne m'en parlez plus, Azazello, j'étais bête, à ce moment-la.

\section{Expressing surprise:}

Russian Ax, помилуйте, - ответил Азазелло, - вас ли я слышу;

English "Oh come," replied Azazello," what did I hear you say?;

German Ach, ich bitte Sie", antwortete Asasello," was muß ich da von Ihnen hören?“"

French He, de grace ! dit Azazello. Est-ce vous qui parlez ainsi ?

\section{Expressing gloat, triumph of disclosure:}

Russian $A x$, жадный старик из Кириафа, - улыбаясь заметил прокуратор; 
English "Ah he must be greedy, that old man from Karioth" said the Procurator with a smile;

German Ach, dieser habgierige Greis aus Kirjath!" bemerkte der Prokurator lächelnd; French Ah! le vieux grippe-sou! dit en rirant le procurateur,etc.

As it can be seen from the examples, the use of interjection to express an emotional state or the attitude of the speaker to a person or to a situation is, as a rule, due to the corresponding lexical units within the micro text, i.e. a sentence, and also in the framework of a bigger context, cf. lexical units приятно, не напоминайте, помилуйте, жадный старик, etc.

Interjections with the word "god" in all languages are used, as a rule, in combination with prototypic (simple) interjections. The most frequent are the models "oh god," "oh gods," "oh my god." Such combinations express surprise, anger, indignation, joy, admiration, etc.

When expressing fear, horror, unpleasant surprise, the word "god" can be used as a synonym to the word "devil": French: bon Dieu de bon Dieu!, dieu(x) de $\operatorname{dieu}(x)$ “damn it!”; English: Jesus Christ! "God”!, “hell!”.

Names of evil spirits in the interjection function are quite frequent in the languages. The corresponding structures express, as a rule, annoyance, irritation, indignation, disgust, neglect, bewilderment, confusion, etc., cf. Russian: $A x$, черти!, Фy, mь черт!, Ни к черту!, Черт возьми!, К черту!, Черт знает что такое!, Черта с два!, Ну тебя к дьяволу!, Что за дьявол!, Сатана меня возьми!, Шайтан тебя возьми!, etc.; English: The devil take it!, Why the hell; German: zum Teufel!, zum Teufel noch mal!, zum Teufel aber auch!; cf. also: alle Wetter! "hell!”; French: au diable!, ah!, diable!, sapristi.

One of the controversial aspects of parts of the speech system is the question of the status of onomatopoetic words (Latin onomatopoetica, English onomatopoeia, onomatopoetic words, sound symbolism, German Onomatopöie, Schallnachahmung, Lautsymbolik, Schallwort, lautmalendes Wort, French onomatopée, etc.). Without going deep into the question of history of the theory of onomatopoeia, this article analyzes the structure of onomatopoeic words in a synchronous plan.

The class of onomatopoeic words can be studied from different points of view: in terms of their phonemic and morphological structure, their classification into groups depending on the physical properties of objects causing the occurrence of certain sound associations as a result of their contact, word-building potentials, and, finally, even their stylistic features.

In their structure, onomatopoeic words can be divided into the following groups.

1. Units consisting of one phoneme, often its lengthening (doubling or tripling): Russian: $\mathscr{H}-\mathscr{H}-\mathscr{H}$ (the sound resembling the buzz of insects), $u$ (the sound made by a person during physical or moral torment, as well as when crying), $y$ (indicates howl, hum); Russian: $y$, yyy (indicates howl, buzz), English: bbbbb (the sound of the engine).

2. Monosyllabic units having two-, three-, and more phonemic structures in which consonant sounds explicitly dominate: Russian: бам, баи, бах, щелк, прыг, скок, чмок, плюх, etc.; English: boom, snap, splash, crunch, buzz, crackle, chintz, woof! woof!; German: bum, peng, plumps; French: boun, brr, crac, flep, splash, pan, bing, pouf, etc.

3. Two-component onomatopoieticons are to some extent characteristic of many IndoEuropean languages: Russian: гав-гав, ку-ку, кря-кря, пиф-паф, кап-кап, кар-кар, мяу-мяy, etc.; English: cow-cow, tick-tack, bow-bow, wuff-wuff, coo-cou, drip-drop, choo-choo "tu-tu" (train movement sound), click-clack, etc.; French: glou-glou (the sound when swallowing a liquid), ronron, flicflac "slap-slap, clap-clap, cap-cap", teufteuf "car puffing", frou-frou "rustling, rustling (leaves, clothes)", etc; German:

XLinguae, Volume 12, Issue 4, October 2019, ISSN 1337-8384, eISSN 2453-711X 
klingkling / klingling “ding-ding”, klitsch-klatsch "smack-smacking”, tick-tack (onomatopoetic image of the clock), etc.

The comparison of a number of languages shows that there is a certain asymmetry between languages in the sense that many onomatopoeic elements exist as independent units in some languages, while in others, their phonetic equivalents are presented in verbal and substantive bases, cf. Russian: плюх, чик-чирик, кря-кря, $\kappa в а-\kappa в а, y-y x$, кар-кар, члок, etc. according to the data of (Wierzbicka, 1976), are interjections (in the Russian lexicographic tradition, all onomatopoeic words refer to interjections), and in English, German, and French such sound complexes are found in verbs that express onomatopoeic actions: English: croak, quack-quack, plump, grunt, etc.; German: grunzen, French: grogner, German: krähen, krächzen, French: croasser. A number of onomatopoietic units reveal phonetically similar correlates in some languages and their complete absence in others, cf. Russian: $2 a-z a, z a-z a-z a$ and verbs in the English language gagle, but: German: schnattern, French: cancaner (about ducks) and criailler (about geese), onomatopoeic words in Russian: дзинь, German: klirr, but in English this onomatopoeia is presented as a verb (to) buzz (about a bee), in Russian: жужжать, in German: summen, and in French: vrombir "buzz".

\section{Conclusion}

Thus, a comparative analysis of onomatopoeic words shows that only a small part of them reveals similarities in different languages: Russian: апчхи, динь-динь, диньдон, динь-бом, кукареку, ку-ку, мяу-мяу, пиф-паф, тик-так, му-у; English: atishoo, atchoo, ding, ding, cock-a-doodle-doo, cuckoo, coo-cow, mew-mew, bangbang, tick-tack, moo; German: hatschi hatzi, kling, klingling, klingeling, kikeriki, kuckuck, miau, pif, paf, tick-tack, muh; French: atchoun, drelin, drelin; ding-dong, cocorico, coucou, miaou, pif-paf, tick-tack, meuh-meuh, meuch.

Based on the analysis of theoretical literature and especially lexicographical sources, one can come to the conclusion that it is necessary to distinguish two independent groups of words in the vocabulary of language - interjections and onomatopoeic words, which does not exclude the possibility of the intersection of their separate subgroups.

If such synsemantic words, like prepositions and conjunctions, perform certain structural functions in the sentence, and particles are both text-oriented and performing certain pragmatic functions in the sentence, then the interjections can be considered as discourse-oriented pragmatic units. Interjections cannot be characterized by any categorical meanings and syntactic functions in a sentence. Often they are themselves equivalent to sentences in which there is no propositive semantics, i.e., events, but there is only an emotional reaction to an event, i.e. perlocution caused by an event, environmental factor is characteristic of interjection phrases. Onomatopoeic words form an isolated group of units that do not perform any communicative and pragmatic functions. They serve as the basis for the formation of verbs expressing certain sounds of animals and natural phenomena.

\section{Bibliographic References}

ALIPICHEV, A.Y. - KHALEVINA, S.N. - TRUBCHENINOVA, A.A. FEDULOVA, A.N. 2017. Practical Solutions to Foreign Language Training Courses Implemented Using Distance Learning Tools. In: International Electronic Journal of Mathematics Education, vol. 12, n. 1, pp. 59-68. ISSN 1306-3030.

APRESYAN, I.D. 2000. New Large English-Russian Dictionary. Moscow: Russkiy Yazyk. ISBN 5-200-02840-X.

BOEVA-OMELECHKO, N.B. - ZHELTUKHINA, M.R. - RYABKO, O.P. MATVEEVA, G.G. - MURUGOVA, E.V. - ZYUBINA, I.A. 2018. Unusual Antonyms: Inter-Part-Of-Speech Interaction in English Fictional Discourse. In: Space and Culture, India, vol. 6, no. 4, pp.112-121. eISSN 2052-8396. 
BULGAKOV, M.A. 1996. The Master and Margarita. Transl. from the Russian by M. Glenny. London: The Harvill Press. ISBN 6433-13647-3.

BULGAKOV, M.A. 2005. Le maître et Marguerite. Paris: Robert Laffont. ISBN 2266-13437-X.

BULGAKOV, M.A. 2006. Master i Margarita. Moscow: OLMA-Press. ISBN 5-22405415-X.

BULGAKOW, M.A. 1983. Der Meister und Margarita. Berlin: Aufbau-Verlag.

CHOLOKHOV, M. 1937. Terres défrichée. Moscou : Cooperative d'édition des ouvriers étrangers en URSS. FB H 1/358. FB R 397/613.

DI PAOLA, B. 2016. Why Asian children outperform students from other countries? Linguistic and parental influences comparing Chinese and Italian children in Preschool Education. In: International Electronic Journal of Mathematics Education, vol. 11, n. 9, pp. 3351-3359. ISSN 1306-3030.

DUDEN. 2005. Mannheim. Leipzig: Dudenverlag. ISBN 3-411-04047-5.

EISENBERG, P. 1994. Grundriss der deutschen Grammatik. Stuttgart: Metzler. ISBN 3-476-01232-8.

GAK, V.G. 2000. Theoretical Grammar of the French Language. Moscow: Dobrosvet. ISBN 5-7913-0035-2.

GENG, X. 2017. The Influence of Teachers' Language on Middle Students' Psychology. In: Eurasia Journal of Mathematics, Science and Technology Education, vol. 13, n. 8, pp. 5637-5644. https://doi.org/10.12973/eurasia.2017.01017a, ISSN:1305-8215.

GRAMMATIK DER DEUTSCHEN GEGENWARTSSPRACHE. 1997. In 3 Bänden. Berlin: Walter de Gruyter. ISBN 3-11-014752-1.

GYAMFI, G. - SUKSEEMUANG, P. 2017. EFL Learners' Perceptions, Practices and Achievement with the Online Learning Program Tell Me More. In: Contemporary Educational Technology, Vol. 8, n. 4, pp. 338-358. ISSN: 1309-517X.

HELLBIG, G. - BUSCHA, J. 1996. Deutsche Grammatik. Langenscheidt. Leipzig, Berlin: Verlag Enzyklopädie. ISBN 3-324-00118-8.

KÖPRÜLÜ, F. - ÖZNACAR, B. 2017. The Views of Lecturers, Students and Administrators on the Impact of Organization in Foreign Language Education to Academic Achievement. In: Eurasia Journal of Mathematics, Science and Technology Education, vol. 13, n. 12, pp. 7865-7874. https://doi.org/10.12973/ejmste/80721, ISSN:1305-8215.

KORKMAZ, S. - GUNEYLI, A. 2017. Impact of Technology-Assisted ContextBased Teaching on the Listening Skills of Teacher Candidates. In: Eurasia Journal of Mathematics, Science and Technology Education, vol. 13, n. 8, pp. 4669-4677. https://doi.org/10.12973/eurasia.2017.00957a, ISSN:1305-8215

KRIVONOSOV, A.T. 1977. Die modalen Partikeln in der deutschen Gegenwartssprache. Göppingen: Verlag Alfred Kümmerle. ISBN 3-87452-364-0.

KUZNETSOV, S.A. 2000. Great Dictionary of the Russian Language. St. Petersburg: Norint. ISBN 5-7711-0015-3.

LONGMAN. 1998. Dictionary of English Language and Culture. Edinburgh: Edinburgh Gate. ISBN 0582302048.

LONGMAN. 1999. Grammar of Spoken and Written English. London: University College. ISBN 0-582-23725-4.

MACMILLAN. 2007. English Dictionary for Advanced Learners. Oxford: Macmillan Education. ISBN 9780230024922.

MURYASOV, R.Z. - SAMIGULLINA, A.S. 2013. Metaforicheskie modeli gordosti $\mathrm{V}$ britanskoy lingvokulture: korpusno-orientirovannyi podkhod. Vestnik Chelyabinskogo gosudarstvennogo universiteta, vol. 10, n. 301, pp. 68-75. ISSN 1994-2796.

XLinguae, Volume 12, Issue 4, October 2019, ISSN 1337-8384, eISSN 2453-711X 
NIKOLAYEVA, T.M. 2005. Functions of Particles in Statements (on the Material of Slavic Languages). Moscow: URSS. 168 p. ISBN 5-354-01056-X.

PAUL, H. 1960. Principles of the History of Language. Translated from German. Moscow: Izdatelstvo inostrannoj literatury.

RIEGEL, M. - PELlAT, J.-CH. - RIOUL, R. 2014. Grammaire méthodique du Françe. Paris: Presses Universitaires de France. ISBN 978-2-13-062756-2; ISSN 1630-5264.

SCHOLOCHOW, M. 1968. Neuland unterm Pflug. Leipzig: Reclam.

SHOLOKHOV, M.A. 1979. Virgin soil upturned. Moscow: Progress. FB M 79$15 / 221$.

SHOLOKHOV, M.A. 1976. Podnyataya tselina. FB M 76-8/246. Krasnoyarsk.

SHVEDOVA, N.Yu. 1980. Russian Grammar. Moscow: Nauka. IB15141.

SIMSEK, A. - ELCIYAR, K. - KIZILHAN, T. 2019. A Comparative Study on Social Media Addiction of High School and University Students. In: Contemporary Educational Technology, Vol. 10, n. 2, pp. 106-119. ISSN: 1309-517X.

SUM, E. - KWON, O.N. 2018. An Analysis of Linguistic Features of the Multiplication Tables and the Language of Multiplication. In: Eurasia Journal of Mathematics, Science and Technology Education, vol. 14, n. 7, pp. 2839-2856. https://doi.org/10.29333/ejmste/90760, ISSN:1305-8215.

UZUN, K. 2018. Home-Grown Automated Essay Scoring in the Literature Classroom: A Solution for Managing the Crowd? In: Contemporary Educational Technology, Vol. 9, n. 4, pp. 423-436. ISSN: 1309-517X.

VALEEVA, R.A. - AITOV, V.F. - BULATBAYEVA, A.A. 2016. The Levels of English Language Acquisition on the Basis of Problem-solving and Product-oriented Tasks in the Multiligual Social Medium. In: International Electronic Journal of Mathematics Education, vol. 11, n. 1, pp. 255-266. ISSN 1306-3030.

WEBSTER'S ENCYCLOPEDIC. 1996. Unabridged dictionary of the English language. New York: Gramercy Books. ISBN 0-517-15026-3.

WEYDT, H. 1977. Aspekte der Modalpartikeln. Studien zur deutschen Abtönung. Tübingen: Niemeyer. ISBN-10: 3484220236; ISBN-13: 978-3484220232.

WIERZBICKA, A. 1976. Particles and Linguistic Relativity. In: International Review of Slavic Linguistics, vol. 1, n. 3, pp. 327-367.

YARTSEVA, V.N. 2002. Linguistic Encyclopedic Dictionary. Moscow: Great Russian Encyclopedia. ISBN 5-85270-239-0.

ZHELTUKHINA, M.R. - VIKULOVA, L.G. - SEREBRENNIKOVA, E.F. GERASIMOVA, S.A. - BORBOTKO, L.A. 2016. Identity as an Element of Human and Language Universes: Axiological Aspect. In: International Journal of Environmental and Science Education, vol. 11, no. 17, pp. 10413-10422. ISSN 13063065 .

\author{
Words: 7739 \\ Characters: 52774 (29,32 standard pages) \\ Prof. Rakhim Zakievich Muryasov, Dr. \\ Department of Romance and Germanic Philology \\ Bashkir State University \\ 19 Kommunisticheskaya Street \\ 450076 Ufa \\ Russia \\ frgf.dekanat@mail.ru
}

